\title{
Pharmacognostic Study of Euphorbia hirta Linn.: An Hyperglyceamic Plant
}

\author{
N'Guessan Bra Yvette FOFIE ${ }^{1}$, Alida Edwige ODOH ${ }^{1}$, Martin Kiendrébéogo ${ }^{2}$, Rokia SANOGO ${ }^{3,4}$, \\ Diénéba KONE-BAMBA ${ }^{1}$
}

\begin{abstract}
${ }^{1}$ UFR Sciences Pharmaceutiques et Biologiques, Université Félix Houphouët Boigny de Cocody-Abidjan, 22 BP 747 Abidjan 22, Côte d'Ivoire.

${ }^{2}$ Laboratoire de Biochimie \& Chimie Appliquées (LABIOCA), Université de Ouagadougou, 03 BP 7021 Ouagadougou 03, BURKINA
\end{abstract} FASO

\author{
${ }^{3}$ Département de médecine traditionnelle de Bamako, Mali \\ ${ }^{4}$ Faculté des sciences Pharmaceutique de Bamako, Mali
}

\begin{abstract}
Objective: To study the preliminary characteristics and pharmacognostic of Euphorbia hirta Linn a ruderal plant, harvested in Ivory Coast. Methods: The pharmacognostic study involved the performance of macroscopic and microscopic examinations of fresh and dried plant. The physico-chemical study involved the determination of moisture content, total ash, ashes sulfuric acid and hydrochloric acid insoluble ashes. Results: The pharmacognostic study has revealed a small herb with finely toothed leaves, asymmetrical, arranged in pairs, opposite a red vinous stem. The inflorescence is composed of small yellowish flowers unisexual, solitary at each node. The fruits are small capsules hairy three valves. The anatomical and histological section of the limbus showed a protruding cylindrical midrib on the underside and slightly depressed on the other. Medullary parenchyma reduced with large polygonal cells and lower collenchyme are cellulosic. Sclerenchyma sheathing the driver device consists of fibrovascular bundle. Secondary and arranged in radial alignment are wood, having vessels with lignified walls and bast with small cells with cellulose walls. The stem, circular, presented a less developed bark, an epidermis, a collenchyme and parenchyma. The developed central cylinder consists of a main parenchyma are observed wherein a centrifugal primary wood, the primary centripetal bast and sclerenchyma in radial alignment around the cambium and the secondary wood. Conclusion: pharmacognostic analysis and physico-chemical characteristics can help in the efficient use of this medicinal plant.
\end{abstract}

Keywords: Pharmacognosy, nutraceuticals, Euphorbia hirta Linn

\section{Introduction}

Immense knowledge of medicinal plants in developing countries needs to be in a monographic. Book on African Pharmacopoeias, collection of several medicinal plants, will play an important role in the transmission of therapeutic knowledge. The World Health Organization (WHO) estimates that more than $80 \%$ of the populations in developing countries rely on traditional medicine for their primary health care [1]. These medicinal plants also play an important role in the socio-cultural field of peoples [2; 3], but serve as a resource for research and development of new drugs [4]. In Africa and other part of the world, several ethnobotanical surveys were performed and result have shown that Euphorbia hirta Linn., is a ruderal plant, known and widely used in the treatment of various ailments such as ear aches, boils and promotes wood healing AKE-ASSI (2011). Also this species is known to have analgesic, antipyretic, expectorant, anti-syphilis and antiviral (AKEASSI, 2011). This species has been the subject of many scientific studies highlighting various activities. The majority of these works concern antimicrobial, antiPlasmodium, antioxidants, anti-diabetic, anti-hypertensive, anthelmintics, anti-allergic, anti-tumor, anti-anxiety, sedative and immunomodulatory, anti-inflammatory, antitetanus, galactogenic), diuretic, cytotoxic, cardiovascular and vasodepressor activities (LANHERS et al., 2005).
This ubiquitous plant is also used in India, Philippines and around the world to treat various contagious and noncontagious diseases. LANHERS et al., In 2005 have already started a monograph of this important plant. We also want to make our own contribution to the monograph of this healing plant.

\section{Materials and Methods}

\subsection{Plant Material}

The plant material consists of the stem with leaves of Euphorbia hirta Linn (Euphorbiaceae) (E h). This plant was obtained in the area of Adzopé, a town in the Agnéby region north of Abidjan (Côte d'Ivoire) The plant has been formally identified by the Laboratory of Botany and a herbarium was established and deposited at the National Centre of Floristic (CNF) University Félix Houphouët Boigny.

\subsection{Methods}

Harvested drugs, were cut, cleaned and then dried at the laboratory temperature $\left(24^{\circ} \mathrm{C}-26^{\circ} \mathrm{C}\right)$. The dry plant material was pulverized using a grinder type Retsch ${ }^{\circledR}$ SM 2000.The plant powder was used for pharmacognostic studies and physico-chemical examination. The fresh organs were preserved for macroscopic, histological and anatomical study. 


\section{International Journal of Science and Research (IJSR) \\ ISSN (Online): 2319-7064}

Index Copernicus Value (2015): 78.96 | Impact Factor (2015): 6.391

\subsection{Macroscopic Studies}

The macroscopic study is a morphological study. This study allowed us to conduct a description of the plant and determine the shape, texture and color of drugs.

\subsection{Organoleptic characteristics Studies}

The study of the organoleptic characteristics covered the powdered drug and concerned the taste, appearance, color and odor of the drug. The smell test is carried out with $1 \mathrm{mg}$ of powdered drug taken between the thumb and forefinger. The odoriferous constituents released slowly and were tested repeatedly. The intensity of the odor was first tested by the following parameters:

"No, Low, Sharp, and Strong" Then was determined odor type:"Aromatic, fruity".

For taste, 5 grams of drugs are placed and kept in the mouth without swallowing, for 10 to 30 seconds. After spit sample, the mouth is rinsed and then enjoyed the taste: «Piquant, Fade, sour, bitter, sweet, salty, warm. This important study allows for the identification of drugs and standardization. The appearance and color required observation.

\subsection{Microscopic Studies}

The anatomo-histological studies have respectively identified tissues and locate secondary metabolites sites. These studies were made on sections of leaves and stem, and the powder of Euphorbia hirta Linn.

\subsubsection{Anatomo- histological Study}

It consisted mainly of an optical microscopic observation. Thin transverse sections were cut using a microtome on fragments of vegetative organs. Then, the sections were treated according to the technique recommended by GABE [13]. The colorant used was carmino- green mirande. The best sections were mounted and stored between slide and cover slip in glycerine medium for observations and pictures taking with a digital camera incorporated in the microscope.

\subsubsection{Micrographic Study}

A small amount of fine powder of drug was mixed with a few drops of $5 \% \mathrm{KOH}$ on an object blade and then covered with a cover slip. The observation was conducted under an optical microscope with $10 \mathrm{x}$ objective. The characteristic elements of the powder drug were noted and photographed.

\subsection{Physicochemical Study}

The study of physicochemical parameters consisted of determining the moisture content and ash content it was performed according to the following protocol:

\subsubsection{Determination of moisture content}

The determination of the water content was performed by the gravimetric method according to the protocol created by Linden and Lorient [14] and Mukherjee [15]: 5 samples of drug powder of $5 \mathrm{~g}$ each were introduced into 5 calibrated crucibles. The 5 samples were dried in an oven at a temperature of $105^{\circ} \mathrm{C}$ for 24 hours. The crucibles were cooled in a desiccators and weighed. The weights obtained were used to calculate the mass loss and calculate the water content of the powder as a percentage.

\subsubsection{Determination of ashes Contents}

2.6.2.1 Total ash: The dried powder used during the determination of the moisture content was reduced to ashes in an oven at $600^{\circ} \mathrm{C}$ for 6 hours. After cooling in a desecrator, the ashes were weighed. The masses obtained were used to calculate the masses of ash and calculate the total ash content, expressed as a percentage.

\subsubsection{Determination of acid insoluble ash in $10 \%$ hydrochloric acid: \\ The total ash obtained was used with $20 \mathrm{ml}$ of $10 \%$ hydrochloric acid. The whole mixture was boiled in a water bath for 15 minutes. The solution obtained was filtered through Whatman paper. The residue was collected in a crucible and calcined in an oven at $600{ }^{\circ} \mathrm{C}$ for 6 hours. The crucible was cooled in a desiccator. The mass of ash insoluble in hydrochloric acid was expressed as a percentage.}

2.6.2.3 50\% Sulfuric Ashes: Five samples tests of $5 \mathrm{~g}$ powder were introduced into crucibles. $5 \mathrm{ml}$ of $50 \% \mathrm{H}_{2} \mathrm{SO} 4$ was added to the contents of each crucible. The whole mixture was placed in the oven at the temperature of $600^{\circ} \mathrm{C}$ for 6 hours. After calcinations and cooling in a desiccator, the ashes were weighed and the mass of sulfuric ash was expressed as a percentage.

\section{Results}

\subsection{Macroscopic Study}

This study allowed us to identify the plant material, and is the first step in the characterization of the crude drug.

\section{Euphorbia hirta Linn.}

F.T.E.A. 3: 726, Keay, F.W.T.A., ed. 1950; Berhaut J. 1967

\section{Morphological characteristics}

This is an annual shrub up to $20 \mathrm{~cm}$ to $60 \mathrm{~cm}$ high. The tinted red vinous stem is circular, solid, and hairy. The leaves are arranged by pairs in opposite and asymmetrical at the base of the stem. The inflorescences are axillary or terminal, and are composed of small yellowish flowers unisexual, solitary at each node. The fruits are three valves hairy capsules (Figures 1 and 2).

\section{Phytogeography}

Euphorbia hirta L. is a plant almost found throughout Africa. It is also found in Asia, Central America and Australia.

\section{Ecology}

Euphorbia hirta L. is a ruderal plant, which grows in various places. Growing in waste places, along roadsides or in rubbish dump area, on vacant land and abandoned plantation areas.

\section{Specimens studied}

Adzopé, February 2012, No. 01. Fofié Abidjan in March 1972, and Adjanohoun Ake-Assi No. 14. Grand Affery, in

\section{Volume 6 Issue 1, January 2017




\section{International Journal of Science and Research (IJSR) \\ ISSN (Online): 2319-7064}

Index Copernicus Value (2015): 78.96 | Impact Factor (2015): 6.391

June 1972, and Adjanohoun Ake-Assi No. 277. Lamto, May 1986, No. 96. Gautier, Adzopé, in February 2012, Fofié (Sn).

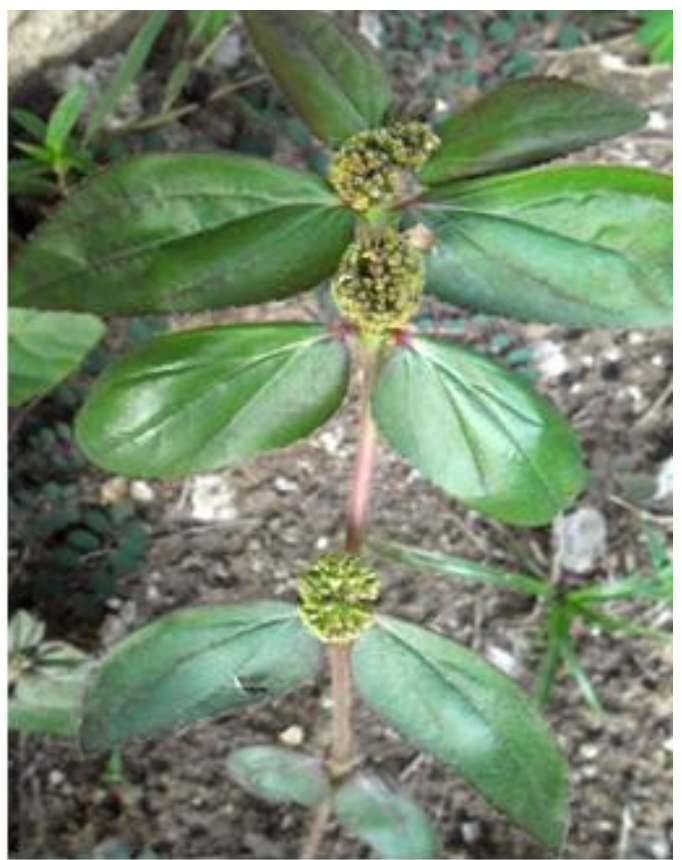

Figure 1. Leaves and stem of Euphorbia hirta L. (source : FOFIE Yvette)

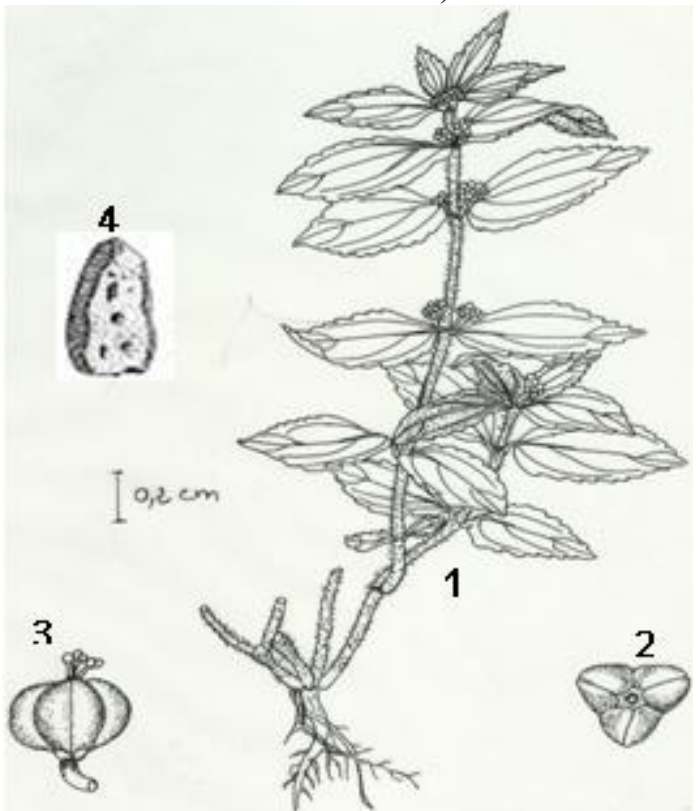

Figure 2. Differents parts of Euphorbia hirta L. (source : FOFIE Yvette) 1. plante stem; 2. Young cyathus; 3. mature Cyathus; 4. Seed

\subsection{Organoleptic Study}

Table 1: Organoleptic caracter of leaves of Euphorbia hirta

\begin{tabular}{|l|l|}
\hline \multirow{2}{*}{ Caracters Drug } & \multicolumn{1}{|c|}{ Euphorbia hirta } \\
Taste & bitter \\
\hline Odor & odorless \\
\hline Color & ashes \\
\hline Aspect & powdered \\
\hline Texture & Coarse \\
\hline
\end{tabular}

All the organoleptic characteristics found in this study are shown in Table I.

\subsection{Microscopic Studies}

Microscopic study of the cross section of the leaf and stem, plays an important role in the diagnostic, identification and differentiation of studied drug.

\subsubsection{Anatomo- histological Study}

The cross section of the lamina (Plate 1) has two areas: a slightly curved midrib at the upper face and deeply bent at the lower side and thinner at the lamina. In the middle of the blade, cylindrical midrib, shows two epidermis (upper and lower) and a mesophyll which includes various tissues (basic and spinal cord parenchyma, primary wood and primary phloem collenchyme).

The epidermis is highly cutinized and also rows of palisade cells. Detectors of bristles are present on the upper side of blade. The spongy parenchyma consists of rounded cells which are some isolated sclerotized. The collenchyma without meatus consisting of cells, uniformly thick and is placed under the epidermis.. The main parenchyma is more abundant on the lower side. The vascular system forms a beam disposed in closed bow with a sheath of primary phloem and primary wood. Medullary parenchyma is very small.

The cross section of the hexagonal stem (Plate 2) has two parts: the bark and the central cylinder. The bark is thin, has three primary tissues (epidermis, cortical parenchyma and collenchyme). The epidermis consists of a single base of small contiguous rectangular cells, the wall is thin and cellulose. The cortical parenchyma consists of several layers of polygonal cells with thin walls.

The central cylinder is more developed than the bark. A fundamental parenchyma is observed in which differs from primary tissues (wood, phloem parenchyma marrow) and two secondary tissues (wood and secondary phloem). The primary wood is centrifuged and the secondary phloem and secondary wood are arranged in radial alignment. The medullary parenchyma, comprises meatus, and is formed of large polygonal cells with cellulose walls.

\subsubsection{Micrographic Study}

Micrographic analysis of the powder has allowed us to detect the drug characteristic elements and also the contaminants and to confirm the purity of the drug. Thus we note the presence:

\subsubsection{Physicochemical study}

This study is essential, in that it helps to identify the bad handling practices and assess the quality of the drug proposed for the study. Various parameters have been defined and reported in Table II.

Table 2: Physicochemical parameters of Euphorbia hirta

\begin{tabular}{|c|c|c|c|c|}
\hline $\begin{array}{c}\text { Parameters } \\
\text { drug }\end{array}$ & $\begin{array}{c}\text { Humidity } \\
\%\end{array}$ & $\begin{array}{c}\text { Total ash } \\
\%\end{array}$ & $\begin{array}{c}\text { Sulfurtic } \\
\text { ash \% }\end{array}$ & $\begin{array}{c}\text { Insoluble ash } \\
\text { in } \\
\text { Hydrochloric } \\
\text { acid \% }\end{array}$ \\
\hline $\begin{array}{c}\text { Euphorbia } \\
\text { hirta }\end{array}$ & $7,73 \pm 0,00$ & $7,48 \pm 0,03$ & $9,05 \pm 0,01$ & $0,8 \pm 0,02$ \\
\hline
\end{tabular}




\section{International Journal of Science and Research (IJSR) \\ ISSN (Online): 2319-7064}

Index Copernicus Value (2015): 78.96 | Impact Factor (2015): 6.391

\section{Discussion}

Our study has focused on examining pharmac ognosic study of Euphorbia hirta. leaves. The scientific books have allowed us to review a large number of bibliographic data on this drug, including the systematic and various domestic uses in traditional medicine. Normalization of the macroscopic and microscopic characteristics of the Euphorbia hirta. Drug remains essential in other to identify and avoid falsification. Thus comparing the cross section of the leaf and stem anatomy showed structural similarities. Both sections have a spinal cord parenchyma, a phloem, xylem and collenchyma. It is observed in a thin sheet cuticle on the upper epidermis and the lower epidermis. Also palisade tissue above the spongy parenchyma. In the stem, secreting pockets are visible on the surface of the medullary parenchyma, as well as supporting cells sclerenchyma primary tissue (primary phloem). The distinct cortical parenchyma can be seen towards the periphery of the cut. Organoleptic characteristics are important in drugs because they play a role in the detection of adulterated or substituted drugs [17]. Thus leaves green in color, emit a very fragrant and aromatic mintyodor when bruised. The powdery appearance of the crushed leaves, with a coarse texture. The micrograph performed on the powder has highlighted a number of characteristic elements namely: the epidermal cells, the type of stomates, the spiral beams, the cystoliths, the trichomes, spiral wooden beam, oily cells, are diagnostic substances for drugs of plant origin. These diagnostic elements are consistent with botanical standards and WHO guidelines $[\mathbf{1 8}, \mathbf{1 9}]$.

The study of physicochemical parameters such as moisture content and ash values are useful as it determines the physiological and nonphysiological state of ash, this will help to determine the possibility of microbial growth and lastly contaminant or impurities. The moisture content of the drug studied had a rate of $7,73 \pm 0,00$, which is below $10 \%$. This result comply with the standards established by the International Pharmacopoeia, because this water content rate , prevent oxidation reactions, fermentation and give less chance to microbial growth and contamination in drugs[20]. Therefore, for proper conservation of drugs made from the leaves of Euphorbia hirta., it would be desirable to use those whose water content is less than or equal to $10 \%$.

The determination of total ash gave us a rate of 7,48 $\pm 0,03$. This value indicates the level of minerals in drugs [21]. Sulfuric ash rate was $9,05 \pm 0,01$. They result from the conversion of organic salts to sulphates [21]. This value substantially equal to the average of $10,80 \%$ found during the determination of sulfuric ash in the different samples of Sclerocarya birrea (A. Rich) Hoscht[22]. Insoluble ash in hydrochloric acid gave a rate of $0,8 \pm 0,02$. Indeed, the ash insoluble in hydrochloric acid tells us about the contamination of the drug by siliceous elements [21]. This result is in agreement with those of [22] and Srikanth et al. [23], who found rate of $0.97 \%$ and $0.5 \%$ respectively.

\section{Conclusion}

This study allowed us to detect the presence of various pharmacognosic parameters in Euphorbia hirta
Linn,according to botanical standard and WHO guidelines. The results of the moisture content content was satisfactory as the level present in the tested drug allows good conservation and prevents the oxidation, fermentation and microbial growth. The value of the ash content did not permit distinction of overload in the drug presented in the form of powder.In light of these results, pharmacognosic analysis and physicochemical characteristics can help in the efficient utilization of this plant, as part of a policy of standardization, identification and research of Euphorbia hirta Linn. drugs.

\section{Acknowledgement}

We extend our gratitude to the Laboratory of Biochemistry applied to the University of Ouagadougou, for his help in achieving the cuts, and the Laboratory of Pharmacognosy Faculty of Pharmaceutical and Biological Sciences of the University Felix Houphouet Boigny for technical assistance in the realization of this work.

\section{References}

[1] Nathiya S, Santhi N, Kalaiselvi S. A comparative study on ontogenic expression of antioxydants and secondary metabolites in Withania somnifera. Int Res J Pharm 2012; 3(1):2010-2015.

[2] Okwu DE. Flavouring Properties of Spices on Cassava Futu. Afr J Roots and Tuber crops 1999; 3(2):19-21.

[3] Okwu DE. Evaluation of the chemical composition of indigenous spices and flavouring Agents. Gl J of Pure and Appl Sc 2001; 7(3):455-459.

[4] Kong JM, Goh NK, Chia LS, Chia TF. Recent Advances in Traditional Plant Drugs and Orchids. Acta Pharm Sc 2008; 24:7-21.

[5] Orwa C, Mutua A, Kindt R, Jamnadass R, Anthony S. Agroforestree database: a tree reference and selection guide. Version 4.0. ICRAF. Centre Mondial de l'Agroforesterie, Nairobi, Kenya, 2009.

[6] Adjanohoun EJ. Médecine traditionnelle et pharmacopée: contribution aux études ethnobotaniques et floristiques en république du Bénin. ACCT, Paris, $1989 ; 274$

[7] Adjanahoun E, Ahyi MRA, Ake-Assi L, Elewude JA, Dramane K, Fadoju S et al. Traditional medicine and Pharmacopoeia. In: Ethnobotanical and Floristic studies in Western Nigeria. Org of Afr Un.'s Sc Tech and Res Comm., Lagos. Nigeria, 1991, 420.

[8] Elujoba AA, Odeleye OM, Ogunyemi CM. Traditional Medicine Development for Medical and Dental Primary Health Care Delivery System in Africa. Afr J Trad CAM 2005; 2(1):46- 61.

[9] Aké-Assi L. Abrégé de médecine et pharmacopée africaine: quelques plantes employées traditionnellement dans la couverture des soins de santé primaire. NEICEDA, Abidjan, 2011, 69.

[10] Ekunwe INS, Melvanique ST, Xuan L, Hengshan W, Yong C, Xiaopu Z et al. Potentialcancer-fighting Ocimum gratissimum Linn. $(\mathrm{Og})$ leaf extracts: increased antiproliferation activity of partially purified fractions and their spectral fingerprints. Ethni \& Dis 2010; 20:1216. 


\section{International Journal of Science and Research (IJSR) \\ ISSN (Online): 2319-7064 \\ Index Copernicus Value (2015): 78.96 | Impact Factor (2015): 6.391}

[11] Aguiyi JC, Obi CI. Hypoglycaemic activity of Ocimum gratissimum in rats. Fito 2000; 71(4):444-446.

[12] Abdullahi M. Phytochemical Constituents and Antimicrobial and Grain Protectant Activities of Clove Basil (Ocimum gratissimum L.) Grown in Nigeria. Int J of Pl Res 2012; 2(1):51-58.

[13] Gabe M. Eléments de techniques histologiques (Fasciculede TP. Université Paris VI) .Université Paris VI, Paris, 1968; 70.

[14] Linden G, Lorient D. Biochimie agro-indusrielle. Ed. 79 Journal of Pharmacognosy and Phytochemistry Masson, Paris, 1994, 360.

[15] Mukherjee PK. Quality control of herbal drugs. Edn 1, Business Horizon, New Delhi, 2002, 187-195.

[16] Hepper FN, Lamiaceae. In Hepper FN, Flora of the WestTropical Africa. Edn 2, Vol. 2, London, 1963, 450473.

[17] Fouraste I. Le contrôle des plantes médicinales. Actualités Pharmaceutiques 1990; (278):55-58.

[18] Kumar S, Kumar V, Prakash O. Microscopic evaluation and physicochemical analysis of Dillenia indica leaf. Asian Pac. J Trop Biomed 2011; 1:337-340.
[19] Nasreen S, Radha R. Assessment of quality of Withania somnifera Dunal (Solanaceae): Pharmacognostical and physicochemical profile. Int J Pharm Sci 2011; 3(2):152-155.

[20] Organisation de l'unité africaine/commission scientifique technique et de la recherche (OUA/CSTR). Pharmacopée africaine, méthodes générales d'analyses. Edn 1, Publisher, Lagos (Nigéria), 1998, 254.

[21] Sambo MH. Etude du traitement traditionnel du diabète par une recette et les écorces de tronc de Manilkara multinervis Dub (Sapotaceae). Th Pharm., Univ.de Bamako, Mali, 2005, 125.

[22] Dagnoko S. Etude de la qualité des feuilles de sclerocarya birrea (A. Rich) Hoscht utilisées dans le traitement du diabète. Th. Pharm., Univ. de Bamako, 2009, 118

[23] Srikanth K, Vikram G, Archana P, Rajinikanth M, Ram SN. Pharmacognostic and phytochemical investigations in Strychnos potatorum Linn. F. J of Pharm and Phyt $2013 ; 2(4): 46-51$.

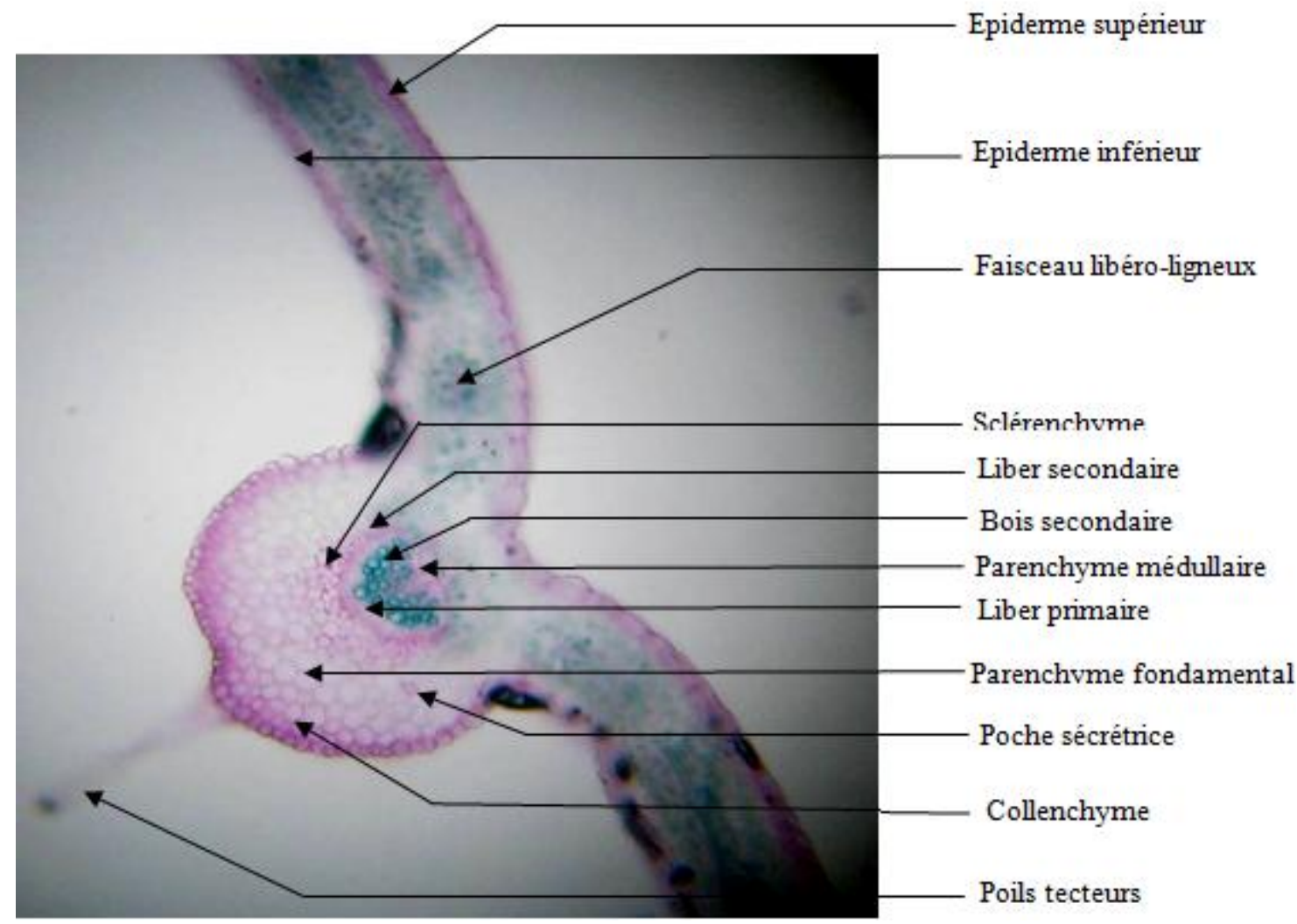

Figure 3 : Cross section of a portion of leaf of Euphorbia hirta L.in the midrib. (Source: FOFIE Yvette) 
Laboratory of Applied Biochemistry (University of Ouagadougou), July 2012

Focus: Gx40; Coloration: Carmino-green; Liquid medium: glycerin water

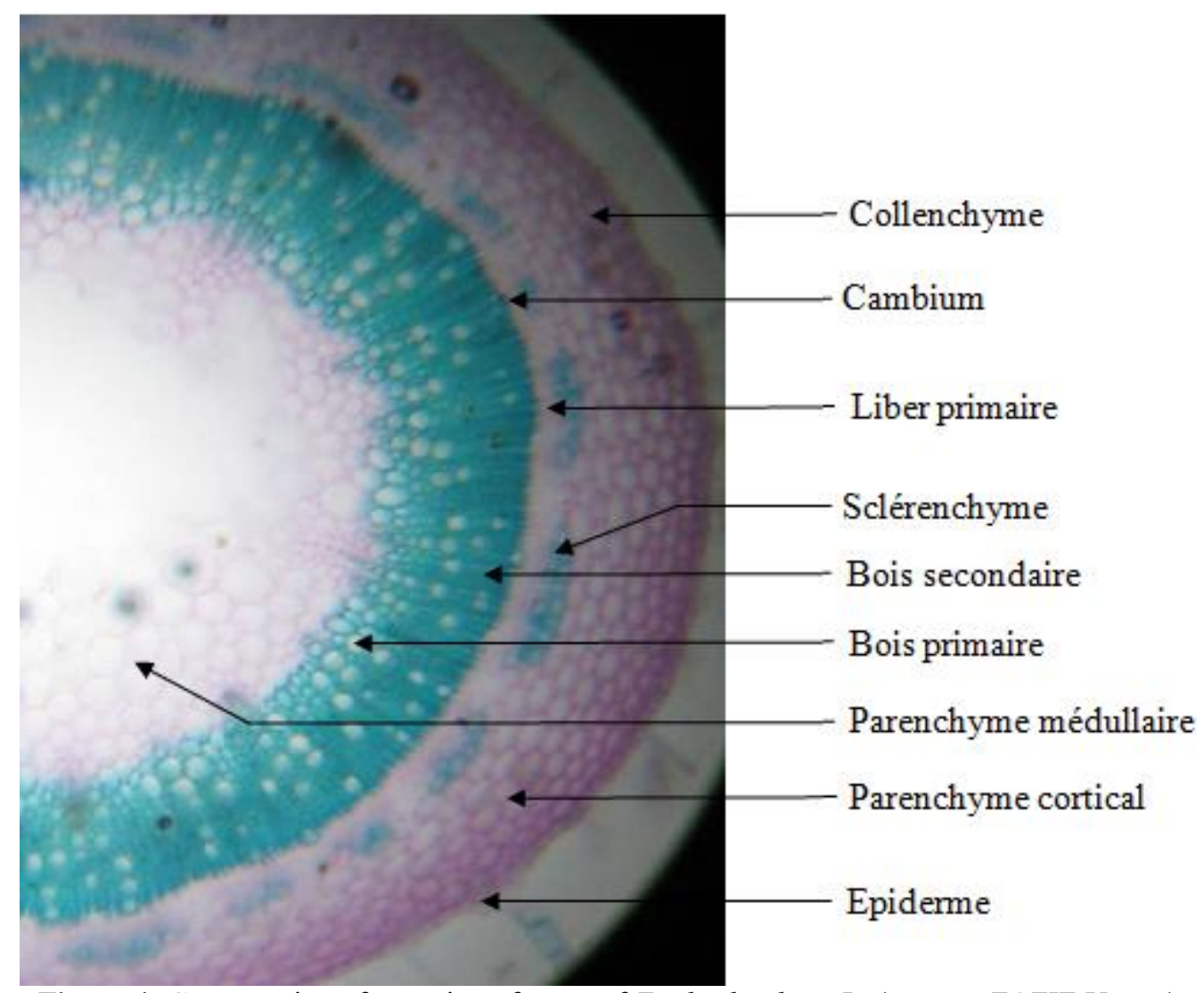

Figure 4: Cross section of a portion of stem of Euphorbia hirta L. (source : FOFIE Yvette)

Plate 2 Cross section of a portion of stem of Euphorbia hirta L.; Laboratory of Applied Biochemistry (University of Ouagadougou), July 2012 Focus: Gx40; Coloration: Carmino-green; Liquide medium: glycerine water

\title{
3.3.2 Micrographie
}

Micrographic analysis of the powder of drug has revealed the characteristic elements. And they are noted:

Volume 6 Issue 1, January 2017

\author{
www.ijsr.net
}

Licensed Under Creative Commons Attribution CC BY 


\section{International Journal of Science and Research (IJSR)}

ISSN (Online): 2319-7064

Index Copernicus Value (2015): 78.96 | Impact Factor (2015): 6.391
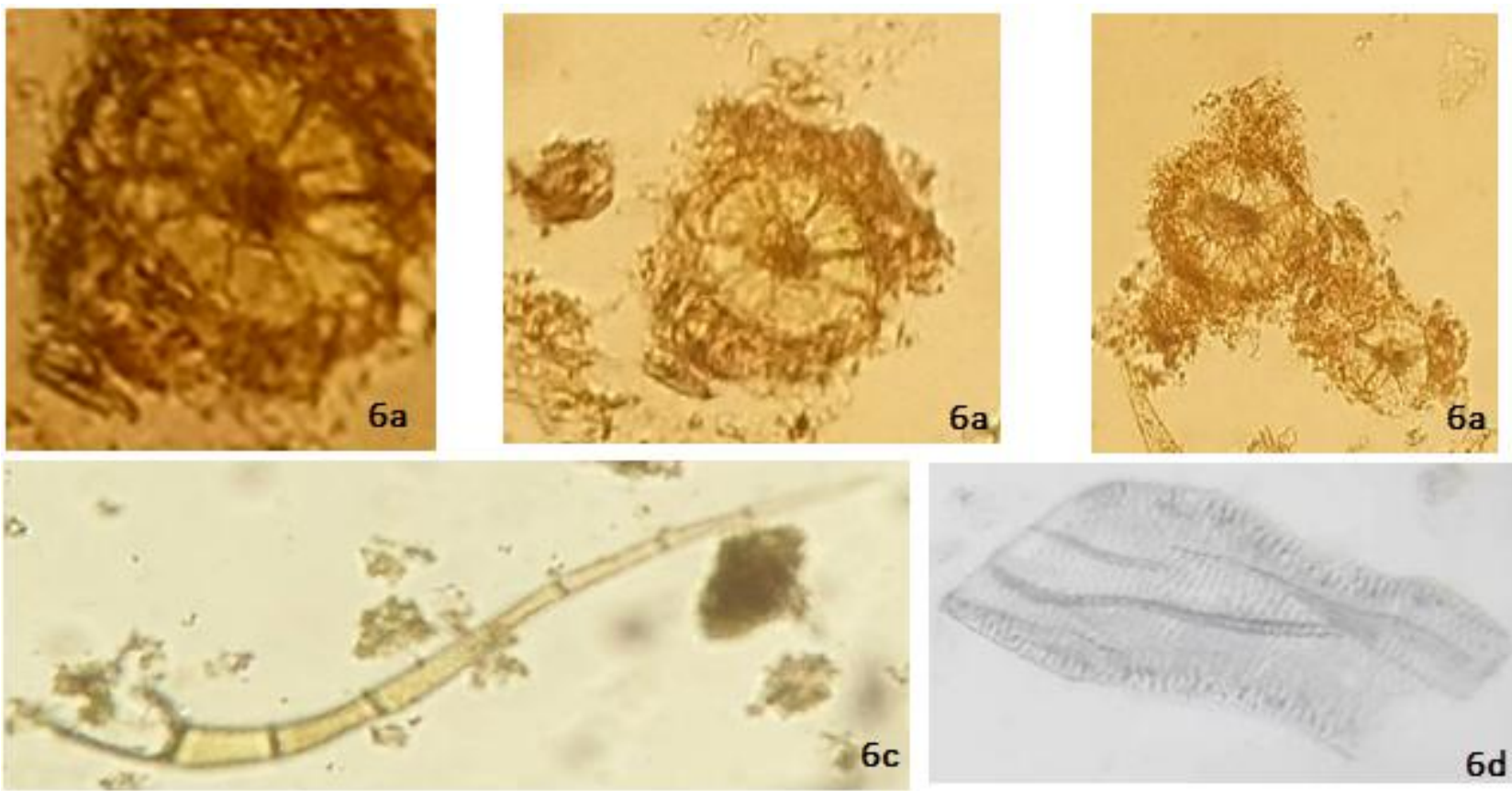

Figure 5: Micrography characteristics of the powder of Euphorbia hirta L. (source : FOFIE Yvette)

The following items are the observed characteristic: $6 \mathrm{a}$. vascular bundles in red circle; $6 \mathrm{~b}$. open vascular bundles; $6 \mathrm{c}$. Trichomes uniseriate multicellular; $6 \mathrm{~d}$. Beams of wood. 